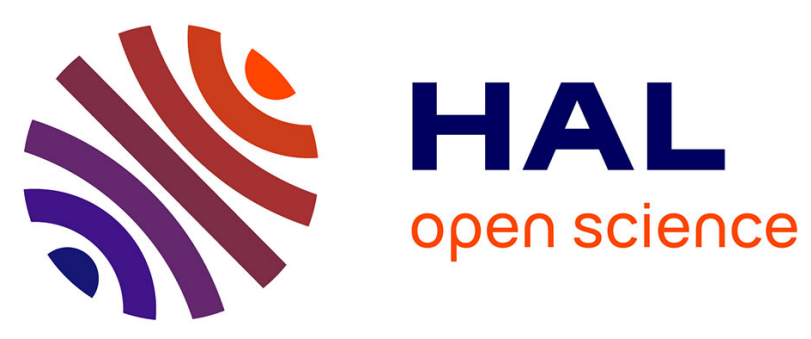

\title{
Two unrelated episodes of Bacillus cereus bacteremia in a neonatal intensive care unit
}

\author{
Nalini Rama Rao, Laure Belotti, Stephanie Deboscker, Marylene \\ Ennahar-Vuillemin, Jerôme de Launay, Thierry Lavigne, Christelle Koebel, \\ Benoit Escande, Marie Helene Guinebretière
}

\section{To cite this version:}

Nalini Rama Rao, Laure Belotti, Stephanie Deboscker, Marylene Ennahar-Vuillemin, Jerôme de Launay, et al.. Two unrelated episodes of Bacillus cereus bacteremia in a neonatal intensive care unit. American Journal of Infection Control, 2014, 42, pp.688-96. 10.1016/j.ajic.2014.01.025 . hal01204360

\section{HAL Id: hal-01204360 \\ https://hal.science/hal-01204360}

Submitted on 27 May 2020

HAL is a multi-disciplinary open access archive for the deposit and dissemination of scientific research documents, whether they are published or not. The documents may come from teaching and research institutions in France or abroad, or from public or private research centers.
L'archive ouverte pluridisciplinaire HAL, est destinée au dépôt et à la diffusion de documents scientifiques de niveau recherche, publiés ou non, émanant des établissements d'enseignement et de recherche français ou étrangers, des laboratoires publics ou privés. 


\section{Two unrelated episodes of Bacillus cereus bacteremia in a neonatal intensive care unit}

Bacillus cereus is an ubiquitous environmental bacterium, isolated in rare instances from invasive clinical specimens. ${ }^{1}$ B cereus is gaining notoriety as a an opportunistic human pathogen associated with severe local and systemic infections among immunosuppressed hospitalized patients. ${ }^{2}$ Premature infants are highly susceptible to infection because of their poorly developed innate and adaptive immune systems and prolonged invasive procedures, such as mechanical ventilation and central catheterization. Most of the literature-reported cases concerned infections of the bloodstream, lungs, and central nervous system. . $^{3,4}$

In August 2011, blood cultures positive for B cereus were obtained from 2 premature babies. Both infants were hospitalized in the same neonatal intensive care unit at the public hospital in Strasbourg, France.

The first of these 2 premature babies was born at 24 weeks and 5 days of gestation and weighed $650 \mathrm{~g}$. An umbilical venous catheter and a percutaneous central venous catheter were implanted for the maintenance of hydration and the administration of drugs and parenteral nutrition. This neonate presented several complications during his stay. He suffered refractory hypoxemia at the age of 19 days, requiring high-frequency ventilation. Progression to chronic bronchial dysplasia led to corticosteroid (betamethasone) treatment for 25 days. The infant also presented a stage-II intraventricular hemorrhage, with bleeding of the vermis, requiring neurologic monitoring. When the patient was 32 days old, a blood culture positive for $B$ cereus was obtained from the arterial catheter. No other bacterial pathogens were found. This episode was accompanied by an inflammatory syndrome, with a C-reactive protein concentration of $92.6 \mathrm{mg} / \mathrm{L}$ and an interleukin- 6 concentration of $391 \mathrm{ng} / \mathrm{L}$ (normal value, $<23 \mathrm{ng}$ / L). Treatment with cefotaxime, vancomycin, and amikacin was administered for 10 days, with a favorable outcome.

The second premature infant was born at 26 weeks and 5 days of gestation and weighed $615 \mathrm{~g}$. An umbilical venous catheter, an intubation, and an injection of pulmonary surfactant were required at birth. On day 5 , signs of infection were observed, with apnea, bradycardia, and gray complexion. Clinical examination revealed a major inflammatory syndrome, with a C-reactive protein concentration of $107 \mathrm{mg} / \mathrm{L}$; interleukin-6 concentration of

N.R. and L.B. contributed equally to this work. Conflicts of interest: None to report.
$13,283 \mathrm{ng} / \mathrm{L}$; anemia, with a hemoglobin concentration of $10 \mathrm{~g} / \mathrm{dL}$; and severe thrombocytopenia. The right atrium had a fleecy appearance on echocardiography, and a cranial ultrasound scan highlighted space-occupying lesions suggestive of brain abscesses. Two blood cultures were set up: the first from a sample taken from the peripheral catheter on day 5 and the second from a sample taken from the central catheter on day 6 . Both were positive for $B$ cereus. The child died at the age of 6 days from multiple organ failure and pulmonary and cerebral abscesses.

In the 2 clinical cases discussed here, the detection of $B$ cereus in consecutive invasive specimens (blood cultures) and the absence of other pathogenic bacteria in these cultures strongly suggest that this opportunistic pathogen was responsible for the symptoms observed in these infants. The strains isolated from the blood cultures of the 2 newborns were compared. The phylogenic relationships between these 2 isolates of $B$ cereus were analyzed with the M13-polymerase chain reaction assay. ${ }^{5}$ The 2 isolates were found to be different. We also determined the toxin profiles of the 2 isolates. The primary toxins of $B$ cereus are hemolysin BL ( $\mathrm{Hbl}$ ), nonhemolytic enterotoxin (Nhe), cytotoxin $\mathrm{K}$ (Cyt k), and cereulide. ${ }^{6}$ Neither isolate produced enterotoxin $\mathrm{Hbl}$ (oxoid kit) or the emetic toxin cereulide (absence of the ces gene). These isolates also lacked the cytK gene. However, both produced the Nhe toxin (Tecra kit), with a high production index at $37^{\circ} \mathrm{C}$. Moreover, both isolates were highly cytotoxic to human epithelial cells. Thus, each of the 2 isolates possessed at least 1 virulent toxin and had microbiologic activities conferring a high virulence potential, ${ }^{6,7}$ potentially accounting for the disease observed in these 2 cases.

In conclusion, we relate 2 cases of $B$ cereus bacteremia in premature infants that caused serious complications in the first newborn and the death of the second child from multiple organ failure and pulmonary and cerebral abscesses. In the 2 clinical cases, $B$ cereus was detected in 2 consecutive invasive specimens, and both infants were hospitalized simultaneously in the same neonatal intensive care unit. However, there was no clear link between these outcomes: the $2 \mathrm{~B}$ cereus strains were genetically different, and the source of contamination was not identified. A hypothesis is that both neonates could have been infected via the point of entry of the umbilical catheter, which was not protected by a dressing, and may therefore have been exposed to environmental contamination. Changes in care practices relating to umbilical central venous catheters should therefore be introduced.

The widespread ignorance of $B$. cereus and of its pathogenic potential makes it difficult to diagnose the infections it causes. As a result, the management of these conditions is often both late and inadequate. Thus, we believe that reporting the cases of $B$ cereus infections among patients, and in particular among the really fragile and exposed neonate population, will help to gain information on this still poorly recognized pathogen and to develop new therapeutic approaches that will protect exposed patients. 
Version définitive du manuscrit publiée dans / Final version of the manuscript published in :

American Journal of Infection Control (2014), Vol. 42, p. 688-96, DOI: 10.1016/j.ajic.2014.01.025

Journal homepage: www.ajicjournal.org

\section{References}

1. Decousser JW, Ramarao N, Duport C, Dorval M, Bourgeois-Nicolaos N, Guinebretière $\mathrm{MH}$, et al. Bacillus cereus and severe intestinal infections in preterm neonates: putative role of the pooled breast milk. Am J Infect Control 2013;41:918-21.

2. Bottone EJ. Bacillus cereus, a volatile human pathogen. Clin Microbiol Rev 2010; 23:382-98.

3. Manickam N, Knorr A, Muldrew KL. Neonatal meningoencephalitis caused by Bacillus cereus. Pediatr Infect Dis J 2008;27:843-6.

4. Frankard J, Li R, Taccone F, Struelens MJ, Jacobs F, Kentos A. Bacillus cereus pneumonia in a patient with acute lymphoblastic leukemia. Eur J Clin Microbiol Infect Dis 2004;23:725-8.

5. Guinebretiere MH, Nguyen C. The sources of Bacillus cereus contamination in a pasteurized zucchini purée processing line, differentiated by two PCR-based methods. FEMS Microbiol Ecol 2003;43:207-15.

6. Stenfors Arnesen L, Fagerlund A, Granum P. From soil to gut: Bacillus cereus and its food poisoning toxins. FEMS Microbiol Rev 2008;32:579-606.

7. Kamar R, Gohar M, Jéhanno I, Réjasse A, Kallassy M, Lereclus D, et al. Pathogenic potential of Bacillus cereus strains as revealed by phenotypic analysis. J Clin Microbiol 2013;51:320-3.

Nalini Ramarao*

INRA, AgroParisTech, Unité MICALIS UMR-1319 La Minière, 78280 Guyancourt, France

Laure Belotti*

Stephanie Deboscker
Marylene Ennahar-Vuillemin Jerôme de Launay Thierry Lavigne

Hôpitaux Universitaire de Strasbourg Equipe opérationnelle d'Hygiène, Strasbourg, France

Christelle Koebel Hôpitaux universitaires de Strasbourg, Laboratoire de bactériologie Strasbourg, France

Benoit Escande Hôpitaux universitaires de Strasbourg Service de réanimation pédiatrique, Strasbourg, France

Marie Hélène Guinebretière INRA, Unité SOPOV, UMR408, Université d'Avignon, Avignon, France

* Address correspondence to Nalini Ramarao, INRA, Unité MICALIS UMR-1319, La Minière, 78280 Guyancourt, France. or Laure Belotti, Hôpitaux Universitaire de Strasbourg, Equipe opérationnelle d'Hygiène, Strasbourg, France.

E-mail address: nalini.ramarao@jouy.inra.fr (N. Ramarao). E-mail address: laure.belotti@chru-strasbourg.fr (L. Belotti). 